\title{
Powerhouse politics and economic development in the North
}

\section{Craig Berry and Arianna Giovannini}

The North of England has rarely featured in national debates in the UK as much as it has done since the 2008 financial crisis, and particularly the 2010-2016 period when George Osborne - a son of London but a parliamentary representative for Tatton in the Northern county of Cheshire - served as Chancellor of the Exchequer. In exploring the pursuit of economic development in the North, this volume seeks to account for both the genealogy of the North's renewed (and possibly short-lived) significance to national politics, and how related political processes can be characterised. Essentially, this work is motivated by the need to understand how the Northern economy has become politicised, the implications of this, and the specific forms that politicisation has taken, after a long period of discursive neglect. In a nutshell: why the North, why now, and what is new? By necessity, the political economy of the North must be studied in relation to the political economy of the UK as a whole, and indeed relationships between the UK economy, its constituent geographies, and the rest of the world. The fact that the North is north of somewhere else is of course a key feature of its political economy. Yet this relationship with the South of England is merely one of an infinite number of ways in which the North is materialised as a political-economic space. The economy of the North of England is produced, and reproduced, by processes of formal and informal governance at myriad of geographical scales, including overlapping (and often contradictory) internal structures and processes within the North. Encouraging greater cross-fertilisation among political economy and economic geography (and related disciplines) is therefore one of the main aims of this volume.

'Brexit' - the UK's decision, in the referendum of 23 June 2016, to withdraw from the European Union (EU) - looms large over the book's content. Like the UK in general, most parts of the North are highly integrated with, and as such dependent upon, at least in the short-term, the wider European economy. More generally, the EU's political and economic structures and processes are in an integral dimension of the (evolving) political economy of the North. Interestingly, the areas of the UK (including large parts of the North) where jobs and production are most dependent on European economic integration (and indeed EU investment) are those that voted most strongly to leave; it is a myth that the big cities, principally London (but also the Northern 'core cities') have higher levels of economic interaction with the continent (Los et al, 2017; Hunt et al, 2016). This is a fact that should not be forgotten, uncomfortable as it is for some commentators: the population of the North chose Brexit, albeit against the advice of the region's leaders - just as Northern elites are often complicit in the maintenance of national political-economic practices, even though (as many chapters of this book will argue) such practices help to keep the residents of the North poorer. Brexit will undoubtedly, over time, reorder the means by which economic life in the North is governed. Yet this is not a book about Brexit and the North. Above all, we do not know, at the time of writing, whether the UK will experience (or choose) a 'soft' or 'hard' Brexit; in practice, there will be degrees of stiffness across the different spheres through which Brexit will be operationalised, and we may yet see the form and extent of Brexit differentiated by geography within the UK. More generally, there are, quite apart from Brexit, 
innumerable local, national and international processes which, as they progress, threaten to reorder economic governance within the North. Historically, the North's development and prosperity have been shaped far more by its status within the British political economy than it by the UK's relationship with the EU.

The book's empirical focus is therefore the multitude of post-crisis policy agendas which have newly exposed the (global) political economy of the North, chiefly Osborne's Northern Powerhouse framing, but also the broader devolution agenda. Exploring the Northern Powerhouse and devolution may (or may not) help us begin to understand the many implications of Brexit for the North, but is also an urgent task in its own right - not least because initiatives related to the Northern Powerhouse and devolution have been largely driven by Whitehall, and Brexit will in all likelihood increase the formal authority of Whitehall over Northern cities and regions (as well as perhaps also offering new opportunities, in the longer term, for more substantial forms of devolution). The fact that the Northern Powerhouse as a specific discursive ploy appears to have been marginalised within the Theresa May government is worth pondering - as it is by several of the book's chapters but should probably not be exaggerated. Moreover, we should not overstate the extent to which the Northern Powerhouse encompassed a distinctive and original set of tangible policy initiatives. Many of the policies that fell under this framework have links with very longstanding agendas, many of which are still being pursued, albeit with a little less fanfare. And crucially, there are as yet no reasons to conclude that the assumptions about the North (and its economic imperatives) which underpinned discourse and practice related to the Northern Powerhouse have been expunged from the architecture of central government - not least because the Northern Powerhouse agenda appears to have merely reflected these preexisting assumptions.

\section{What is the North?}

We recognise that we mean by 'the North' is not entirely obvious from the term itself. At the same time, notwithstanding some debate over 'borderline' areas, we would contend that most people in the UK have a general understanding of what is, and what is not, considered the North of England, and that this understanding is usually upheld in scholarship on the North. The book has not been compiled on the basis of an editorial line on how to define the North, although it is worth noting that all chapters implicitly share the view that the definition of the North that has at times been explicit in officialdom - being composed of the regions of the North West, North East and Yorkshire and Humberside - is largely accurate.

It is of course not possible to tell the story of the North without referring to places unambiguously outside of these three regions. This is in part, firstly, because other parts of the UK resemble to North in terms of socio-economic outcomes. Danny Dorling (2010; 2011), one of the leading scholars of the so-called 'North-South divide', actually includes Scotland, Wales, Northern Ireland and a large chunk of the Midlands in his definition of the North, given similarities in outcomes such as household income and life expectancy. The Northern regions are disadvantaged, but not uniquely so within the UK. It is also because, secondly, the North is not a distinct economic space. Generally speaking it obviously interacts with the domestic and international economies; moreover, we should not assume that the North's constituent parts interact with each other economically more than they do with 'exogenous' areas. We cannot understand how the Northern economy (or economies) functions without also understanding these wider relationships and processes. Yet none of this means that the North cannot be distinguished analytically. The North may not be uniquely disadvantaged but there may be (relatively) distinct explanations for its disadvantage. Similarly, while it may be 
necessary to locate the North in its wider political-economic contexts, the way in which these contexts shape specifically Northern economic life is a legitimate object of inquiry.

We would also offer a note of caution about a predominantly spatial understanding of the North. The book's central disciplinary perspective is that of political economy, and its analysis generally focuses therefore on how the exercise of power across multiple spheres shapes Northern economic life, or the way in which the North interacts with the rest. The relevant spheres may be local, national or international. The lack of any formal institutional framework through which the North as a whole is governed may make this exercise challenging empirically - but arguably underlines the urgency of understanding the wider political processes which shape the North (Hayton, Giovannini and Berry, 2016). A political economy perspective also encourages us to focus on the social construction of the North, and the framing of its spatial identity by elite forces. Any simple understanding of the North's characteristics or boundaries is belied by an inherently complex social reality, but the delineation of the North is itself an act of power in need of interrogation (Paasi, 2000; Jessop, 2012 ; 2015). Indeed, it is not difficult to detect the power relations implicit in the notion that the North is different, unique or even 'foreign' from English or British norms - a notion that is reinforced even in narratives and policy initiatives that are designed ostensibly to benefit the North (such as the Northern Powerhouse, or the coalition government's earlier 'Northern Futures', or New Labour's 'The Northern Way' - all of which enjoyed local as well as national support among policy elites). The North has acquired meaning in subservience.

\section{The political-economic environment}

As with any volume of this nature, the book's empirical scope is broad, and its analysis multitonal. However, four key dimensions of the North's political-economic environment underpin the book's intellectual agenda and its contribution to the existing literature:

- The persistence of geographical inequalities within the UK, and in particular between the North and South of England.

- Longstanding (yet partial) attempts to devolve powers from the UK central government to the North and its localities.

- The experience of deindustrialisation in the North (and the imperative to 'rebalance' the economy towards industry in the wake of the financial crisis).

- A wider, transnational process of capitalist restructuring within which the North is implicated quite acutely.

Undoubtedly, as suggested above, the notion of North-South divide has become a trope for the persistence of economic - but also political, social and cultural - inequalities between the North and South of England (Martin, 1993; Jewell, 1994). The concept rests on the presence of structural differences (in terms of economic development, employment, education, life expectancy, etc.) between a prospering South and a 'lagging behind' North (Dorling, 2010). Crucially, as Baker and Billinge (2004) argue, the North-South divide has a history both as a reality (especially in economic terms) and as a representation of reality (portrayed and reproduced in a number of political, social and cultural narratives as well as in the popular imagination), which has persisted in shaping the spatial imaginary of the North as subordinated to the South. There are serious and longstanding geographical inequalities within the UK, for which (within England at least) the North-South divide is a simplifying but not simplistic description. From a political economy perspective, however, it is important to note additionally that the dichotomy underpinning the North-South divide has been 'institutionalised' by successive governments since at least the 1970s. Indeed, the need to 
address disparities between the North and the South has provided the rationale both for economic and social reforms and, most recently, for justifying state restructuring.

Yet an agenda of helping the North rather than empowering the North (and indeed disempowering the South), invariably pursued without a clear analysis of why the NorthSouth divide exists, has led to uneven, partial and 'messy' attempts at bridging the NorthSouth divide. These attempts often crystallise inequalities, as Northern economic development is reduced to a fairly technocratic area of social or regional policy, while the economic development of the country as a whole remains the focus of the sovereign institutions at the centre. The Northern Powerhouse, insofar as it can be associated with concrete policy initiatives, ostensibly represents another attempt to help the North through the lens of national institutions and a national growth model, based on the notion that the North needs to 'catch up' with the South. Furthermore, the agenda implicitly inscribes the notion of Northern dependency on the already-existing economic powerhouse in the South, and as such blurs seamlessly into an austerity agenda which prescribes less central government support for Northern regions, so that the North might be better equipped to help itself (Berry, 2016a).

Of course, many in the policy-making community would argue that the centre has sought to empower the North (as well as other regions and nations in the UK) through devolution. Yet moves towards devolution are tied up in the institutional churn that characterises the centre's orientation towards the North more generally, and in recent years have also been strongly associated with austerity (Pike et al, 2016). Devolution to the North does, however, have a longer genealogy. Over the past decades (and in particular since 1997) devolution has been presented by successive governments as a means to address the governance of uneven development in England. Decentralisation, though, has itself developed in an uneven manner, taking different forms and meanings, and focusing on different scales under different administrations. From the late 1990s onwards, devolution to the North of England revolved around a diverse set of 'spatial imaginaries', spanning from administrative regions (as the basis for Regional Development Agencies and directly elected regional assemblies), to cities and/or city-regions and, most recently, combined authorities of local councils (usually linked after 2010, loosely, with a Local Enterprise Partnership) (Giovannini, 2016). The common thread to these approaches is that they frame the North within a centripetal narrative according to which Whitehall 'knows best' how to address the North's problems - leading to devolution policies negotiated mainly between national and local elites, and involving feeble powers, modest budgets, vast liabilities and the maintenance of substantial control from the centre (Giovannini, 2016: 592; Deas, 2014). Thus, devolution in the North of England has followed a characteristically bewildering and underwhelming path - leading to complexity, experimentation, fragmentation and incoherence with largely negative implications for territorial equity and justice (Pike and Tomaney, 2009), as well as for local politics and democracy (Tomaney, 2016; Prosser et al, 2017).

Indeed, the problematic nature of devolution in the North has been thrown into sharp relief in the context of the Northern Powerhouse, showing continuity with past experiences. On the one hand, the devolution deals currently endorsed by the government continue to be tightly connected with the pursuit of local economic growth, which is one of the leitmotifs of the Northern Powerhouse agenda. On the other hand, however, the economic dividend of devolution deals grounded in the idea of agglomerative urban growth is far from clear (Haughton et al, 2016). In essence, the Northern Powerhouse is being advanced within a patchwork of 'territorial fixes' rather than coherent and cohesive decentralisation policies across the North. Some argue that devolution in the North, as a result, is promoting a 'deep(ening) neoliberalisation of territorial politics' (Brenner et al, 2010), in which interregional inequality is not only tolerated, but becomes the norm (Deas, 2014: 2309) - and 
local elites, rather than central government, will be the principal culprits of failures to 'catch up'. While this understanding is arguable, we can certainly say, more generally, that moves towards devolution have always had a rather ambiguous identity with the politics of economic development in the North, embodying a dynamic of emasculation through democratisation. Despite the apparent wake-up call of the 2008 crisis, there are few reasons to believe that the present moment is different substantively from previous devolutionary moments in this regard.

The main economic context in which concerns about the North-South divide, and efforts towards enabling the North to develop, have emerged (and re-emerged) is deindustrialisation. In recent years, especially since the 2008 crisis, national policy elites have begun to problematise the decline of manufacturing industries and advocate a 'rebalancing' of the UK economy from London-based (financial) services back towards manufacturing industries based predominantly in the North and Midlands. As such, both the experience of deindustrialisation, and more recent attempts to mitigate its seemingly negative consequences, form a crucial background to the book's analyses of the political economy of development in the North. Deindustrialisation in terms of declining employment in manufacturing industries has of course been experienced throughout the advanced capitalist economies, rather than the UK alone. However, it has been steeper in the UK elsewhere, and ultimately led to significant reductions in manufacturing output as well as employment, associated as it is with the UK's longstanding productivity problem (Berry, 2016c; Rowthorn and Coutts, 2013). Deindustrialisation also has particular geographical implications for the UK, given that it is predominantly London and the South East where high-value 'post-industrial' economic activities are concentrated. While some Northern cities have now developed strengths in some knowledge-based service industries, many places remain scarred by the loss of largescale manufacturing employment, and the UK has a much more significant degree of inequality within regions than comparable countries, as towns and smaller cities in the North are 'left behind' by regional centres (Hudson, 2013; McCann, 2016).

Ostensibly, rebalancing signifies an attempt to revive UK manufacturing, particularly in the North. There have been several incarnations of an industrial strategy for the UK in recent years, most obviously under Vince Cable (as Secretary of State for Business, Innovation and Skills) under the coalition government in 2012, and after the ascendance of Theresa May to the premiership in 2016. Both initiatives have earmarked the growth of high-value manufacturing as important to the UK's economic future, although both, despite the obvious geographical connotations of the wider rebalancing agenda, are also relatively 'place-blind' (Berry, 2016b). Furthermore, we can question the extent to which rebalancing is a genuinely transformative agenda. Clearly, the notion of rebalancing suggests that there once was balance, and the implication therefore is that all is required is a set of technocratic adjustments to the economy's current path, rather than wholesale reform. There are no problems inherent in the UK economy's sectoral or geographical composition; rather, its constituent industries and localities have simply become a little disorderly. That the Northern Powerhouse agenda is understood as helping to deliver rebalancing helps us to understand both its limited ambitions, and the concentration of the agenda on helping the North to catch up rather than on the relationship between the North and other parts of the British political economy (Berry and Hay, 2016; Froud et al, 2013; Lee, 2015).

The UK's experience of, and quintessential acquiescence to, deindustrialisation cannot be divorced from much broader processes of restructuring in the global capitalist system. This restructuring, known simplistically as 'globalisation' but associated in more sophisticated terms with the development of new global production networks as the West deindustrialises, is inherently spatial in nature. It both emerges from and reinforces the existence of 'core' and 
'periphery' zones within the global economy, as large cities within the West become more integrated with each other and cities in the rapidly industrialising semi-periphery. Geographical inequalities within highly developed economies are at the same time enhanced, as core cities become increasingly detached from their neighbouring regions domestically (Peck and Theodore, 2007). One of the ironies of globalisation is that it has actually taken the form of localisation, whereby economies trade in intermediate or semi-finished goods with nearby countries rather than specialising in particular finished goods for which a wider, more global market exists. More trade over smaller distances, and new, complex patterns of specialisation and convergence are the results of this transformation (McCann, 2008). The exception that proves the rule is financial services, as services that are developed and produced entirely within a single city, that is, financial centres such as London, are sold as finished products - although the customers generally, and by necessity, come to London to consume these products rather than importing them across borders.

These macro-level processes cannot possibly account for recent developments in the Northern economy in any satisfactory way. While global capitalist restructuring appears to have exacerbated inequalities between England's North and South (McCann, 2016), in many ways the UK's extant economic geography provides an exemplary case of the core/periphery dynamics that have emerged in other developed economies. Nevertheless, these broader, global processes are an important part of the picture of what economic development looks like, and could look like, in the North. It is interesting that many of the largest cities in the North have adopted the mantle of 'core cities', although they are not in any meaningful sense part of the 'core' zone of the global economy in the way that London is. It is hard to imagine, given the deeply embedded nature of North-South relations in the UK, that entering the ranks of global core cities alongside London could become a realistic goal for Northern cities in the foreseeable future, especially in the wake of Brexit. The more pertinent point for our purposes, perhaps, is that both national and local political leaders in the UK have internalised this process of restructuring to the extent that it is seen as the only possible route to sustainable economic development, even if the route is a highly uncertain one for most localities. This might help us to understand why there has been so little sustained opposition within public debates to the coalition and Conservative governments' agendas around devolution, local growth and the Northern Powerhouse, and indeed why national and local elites have often sought to insulate these agendas from democratic scrutiny.

\section{The book}

The idea of this book stems from a workshop held at the University of Sheffield in November 2015, titled 'The Political Economy of the Northern Powerhouse', which was part of a series of events organised by the White Rose Consortium for the North of England project (WRCN) in 2015-16. The workshop brought together a unique range of scholars from several disciplines, united most of all by wonderment that the issues around the political and economic life of the North of England most of us had been studying - and indeed living, in most cases - for many years had suddenly been thrust into the national spotlight. More specifically, contributors were asked to consider:

- The uneven and evolving nature of economic life in the North of England, including industrial composition, and the impact of social structures and processes on the Northern economy.

- The economic relationships between Northern regions, the rest of the UK, and the European and global economies. 
- Approaches to economic development (and its governance) in policy-making processes and/or academic research.

- The relationship between culture, identity and political processes within or affecting the North, especially in relation to the rise of Englishness as a political identity.

- The operation of political parties (and their sub-national structures) within political processes within or affecting the North.

- The relationship between urban development, economic geography and political processes within or affecting the North.

- The emerging character of UK central government (which will of course retain significant powers over macroeconomic policy) as political authority becomes more localised.

- Epistemological and methodological issues related to the analysis of the political economy of the North of England.

Admittedly, this was a very ambitious agenda, which we inevitably did not manage to meet in full. But we considered it an urgent agenda nevertheless - and we still do. This book has been compiled in hope of advancing it further, concretising the fruitful exchanges generated on the day, and hoping to inspire further research and debates in the testing years ahead for the North. We are grateful to the White Rose University Consortium for funding the workshop and the wider WRCN project. Most of the chapters in this volume are updated versions of the papers presented at the workshop, and those that have been added are authored by some of the workshop's non-presenting participants, inspired by the discussion it encompassed.

The book is organised into three parts. The first part focuses on economic policy-making structures and practices in the context of the evolving economic relationships between the North and the rest of the UK. In chapter 1, Martin and Gardiner report on a major new research programme into structural transformation within urban economies to assess the scale of the challenge facing those concerned with local economic development in Northern England. They show that a North-South pattern of spatial economic imbalance was already well-established in the nineteenth century, despite popular misconceptions of the North's industrial past. Using novel data, the authors then show how major Northern cities have lagged even further behind in recent decades in terms of the growth of employment, output and productivity. Crucially, this problem is not readily attributed to Northern cities being 'too small', as the advocates of vogue-ish thinking around urban agglomeration might claim; what is arguably more important is the fact that London has long enjoyed the position of hosting all of the key economic, financial and political institutions that govern the economy and determine national economic policy. As such, spatial imbalance in the UK is not solely an economic issue: it is also one of a major spatial imbalance in the location and operation of the key levers of economic, financial, political and administrative power. The authors conclude that spatial economic imbalance in the UK is an entrenched, persistent and indeed institutionalised feature of the national political economy, and that the partial devolution of fiscal powers and policies to city-regions in the North will have only a limited impact on what has long been a systemic and deep-seated London-centric bias in Britain's national political economy.

Lee takes up similar themes in chapter 2. He argues that the political economy of England's Northern Powerhouse cannot be understood in isolation from that of its 'Southern Powerhouse' neighbour. The chapter challenges the notion that the UK's relative economic decline can be attributed to the absence of a state-led technocratic industrial modernisation programme, and contends instead that public policy and governance arrangements in contemporary England are the outcome of the long-term strategic priorities of the English (latterly British) developmental state, fashioned by its pilot agency, the Treasury. As such, 
the Northern Powerhouse agenda should be understood as simply the latest political narrative in a longstanding tradition of British statecraft which has subordinated the interests of development in the North of England to those of the global financial and commercial interests of the City of London.

In chapter 3, Berry focuses more forensically on issues raised in chapters 1 and 2, that is, the decline of manufacturing industries in Northern England. The chapter is structured around 'the three Ds' of the Northern Powerhouse: deindustrialisation, devolution and, most arrestingly, 'de-development'. Contesting the view that the Northern Powerhouse can be understood primarily as a process of institutional or constitutional reform, it instead locates the agenda within the long (but limited) history of UK industrial policy. It argues that regional policy has always substituted for industrial policy in the UK state's 'horizontal' support for manufacturing, and that devolution to Northern city-regions is therefore the ultimate expression of laissez-faire industrial policy. However, the agenda touches upon postcrisis concerns around place and empowerment, even while it serves to reduce the control of Northern citizens over their own local economies by offering only a narrow understanding of how economies develop. Indeed, insofar as Northern regions have very little control over the structures and practices that govern its economic make-up, and as such have no way of bucking its subservient role within processes of global capitalist restructuring, the North may be stuck in a de-development trap. In chapter 4, Flanagan and Wilsdon ask whether the longstanding concentration of science-related investments - one of the few functioning features of UK industrial policy - is likely to be reversed. They document the bias towards 'golden triangle' investments within UK science and innovation policy on the basis of a place-blind policy framework, and consider the extent to which more recent developments show that the North's scientific assets, such as its world-class universities, are finally beginning to be recognised by policy-makers as integral to the UK's economic prospects.

The second part of the book focuses on city-regional governance and local politics, with each chapter considering the myriad ways in which issues around place are becoming an important feature of British political life. In chapter 5, Gray, Dickinson and Pugalis consider whether the approach to subnational development that underpins the Northern Powerhouse narrative represents a serious and coherent attempt at bridging the economic North-South divide. The analysis focuses on the evolution of the government's cities and local growth agenda (CLOG) in the North of England and its relationship with the Northern Powerhouse, with particular emphasis on agglomeration theories, and draws on empirical data in the form of interviews with stakeholders in the North. The authors find several flaws in this relationship, arguing that the Northern Powerhouse is a 'piggyback initiative' that has spawned a wide range of policies, interventions and funding announcements with little attempt at strategic co-ordination. They conclude that subnational policy in the North, as manifest in CLOG and the Northern Powerhouse, is distinctively disorderly. This approach limits the development of place-specific governance and policy and, most importantly, is unlikely to lead to a rebalancing of the economy.

In chapter 6, Giovannini develops a critical analysis of the uneven governance of devolution deals in Yorkshire. Drawing on the findings of interviews with local stakeholders, she assesses the opportunities and challenges offered by devolution deals in the region. She concludes that although economic development is perceived as a key asset of devolution, in practice the current top-down approach to 'devo deals' is promoting local divisions and is fostering intra-regional inequalities. As a result, devolution in Yorkshire is leading to a system of governance that is highly fragmented and problematic in political, economic and democratic terms. Crucially, the new fractures created within Yorkshire could end up hampering from within not only the devolution process, but also the wider Northern 
Powerhouse agenda. In chapter 7, Evans and Blakeley focus on the other side of the Pennines, in assessing the inter-connection between devolution to combined authorities (CAs) in the North and the Northern Powerhouse, based on the benchmark case study of 'Devo Manc'. The authors find that the institutional maturity of Greater Manchester Combined Authority (GMCA) and its central role in the promotion of the Independent Economic Review to develop an economic strategy for the Northern Powerhouse have been key to defining its leadership role in the context of the CAs initiative. They argue therefore that in the existing governance vacuum of the Northern Powerhouse, the leadership of the GMCA will provide a fulcrum. However, they also emphasise that there remains uncertainty about the long-term sustainability of both the CAs project and the Northern Powerhouse, and suggest that decisions concerning the Northern transport interconnectivity and the impact of the "metromayors' elections will be decisive tests of their viability.

In chapter 8, Martin, Schafran and Taylor consider devolution in the North of England through the lens of history. Arguing that current debates about Northern English cities and their role in national economic strategies cannot be read simply through contemporary politics, they trace the long history of policy and planning discourses about the North, of which the Northern Powerhouse, they argue, is the latest incarnation. Drawing on Dave Russell's (2004) chronology of key historical moments in which Northern English cities have been particularly significant in cultural narratives of the nation, the authors develop an analysis of concurrent tensions in debates about planning and governance which have shaped specific (and often 'negative') constructions and perceptions of the North. Focussing on representations about the North of England over the last two centuries, their study sheds light on the presence of four interlocking themes: the dominating role of London in directing debates about the North; a tension between political and spatial approaches to planning; the characterisation of cities in the North as intrinsically problematic; and the continued issue of poverty in these cities.

The third part of the book deals more specifically with issues of inequality in the North, and the possibility that these may be exacerbated by initiatives related to the Northern Powerhouse, particularly in the context of austerity. In chapter 9, Jones, Beel and Rees Jones focus on the way in which city-regions (as the central spatial political units within the Northern Powerhouse) are constructed, and shed light on how civil society is being (re)positioned within a fast-changing governance landscape. To achieve this, they draw on the case of two key city-regions within the Northern Powerhouse: Greater Manchester and Sheffield. By analysing the findings of interviews with civil society actors in these two areas, the authors argue that the current approach to city-regional economic development and devolution is falling short of its promises and, by perpetuating uneven dynamics of 'inclusion' and 'exclusion', continues to exacerbate uneven development and undermine the project of spatial rebalancing in the North. Crucially, they note the presence of a clear divide between the actors who have been enabled to have a voice and 'lead' within the devolution city-region agenda and those who have been marginalised in this process. They emphasise how new 'citizenship regimes' implemented within city regions place civil society outside of decisionmaking processes that underpin devolution deals, whilst simultaneously (and paradoxically) expecting civil society to deal with the fallout from continuing uneven development, sociospatial inequalities and austerity. They conclude that there is a need to integrate the 'social' alongside the 'economic' within both devolution and the Northern Powerhouse if a more inclusive growth strategy, embedded in a sustainable system of governance, is to be achieved.

In Chapter 10, Muldoon-Smith and Greenhalgh examine how the Northern Powerhouse agenda will be financed, focusing principally on the government's Business Rate Retention Scheme (BRRS). The chapter explains local government finance in England, focusing on its 
evolution from a centralised model to one based on the parallel rubrics of localism and local economic growth. The chapter's analysis focuses on three inter-related themes: liability and growth potential, demand divergence, and the nature of local commercial property markets. The authors conclude that, by bringing the civic realm into closer proximity to already financialised property markets, the BRRS has begun to roll-out the conditions that will allow parts of the Northern Powerhouse to enter an era of 'civic financialisation' and entrepreneurial activity. However, asymmetries between commercial property markets, economic conditions and welfare needs across the North of England could also create a defined set of 'winners' and 'losers' (that is, those that can take part in autonomous civic financialisation and those that remain reliant on a system of redistribution and equalisation) thus casting doubts on the coherence and long term sustainability of the Northern Powerhouse agenda and the way in which its financed.

Chapter 11, by Bailey, covers similar territory, albeit focusing on the recomposition of the tax system within the UK more generally, and in particular the implications of this process for local economic development in the North. The chapter argues that tax reform will concentrate capital available for reinvestment in those local economies which are already affluent and growing, and in all likelihood further disadvantage Northern regions. The recomposition of the tax system therefore inaugurates a 'race to the bottom' between polities who will be encouraged to offer increasingly 'business friendly' tax environments. This is being discursively rationalised as part of a strategy to address the UK's uneven development, but instead is likely to exacerbate regional inequalities. Finally, the concluding chapter draws together the main themes of the book, summarises the lessons for future scholarship on the North, and sketches an alternative policy agenda designed to deliver economic development and political empowerment for the North.

\section{References}

Baker, Alan and Billinge, Mark (2004). Geographies of England: The North-South Divide, Material and Imagined, Oxford: Oxford University Press.

Berry, Craig (2016a). Austerity Politics and UK Economic Policy, Basingstoke: Palgrave.

Berry, Craig (2016b). 'Industrial policy change in the post-crisis British economy: policy innovation in an incomplete and institutional environment', British Journal of Politics and International Relations, 18(4), 829-847.

Berry, Craig (2016c). 'UK manufacturing decline since the crisis in historical perspective', SPERI British Political Economy Brief No.25. Available at:

$\mathrm{http}$ ://speri.dept.shef.ac.uk/2016/10/20/british-manufacturing-has-entered-a-new-phase-ofdecline-new-speri-brief/ [accessed 14 March 2017].

Berry, Craig and Hay, Colin (2016). 'The Great British 'rebalancing' act: the construction and implementation of an economic imperative for exceptional times', British Journal of Politics and International Relations, 18(1), 3-25.

Brenner, Neil, Peck, Jamie and Theodore, Nik (2010). 'After neoliberalization?', Globalizations, 7(3), 327-345.

Deas, Iain, (2014). 'The search for territorial fixes in subnational governance: City-regions and the disputed emergence of post-political consensus in Manchester, England', Urban Studies, 51(11), 2285-2314. 
Dorling, Danny (2010). 'Persistent North-South Divides', in N.M. Coe and A. Jones (eds) The Economic Geography of the UK, London: Sage, 12-28

Dorling, Danny (2011). So You Think You Know About Britain, London: Constable.

Froud, Julie, Johal, Sukhdev, Law, John, Leaver, Adam and Williams, Karel (2011). 'Rebalancing the economy (or buyer's remorse)', CRESC Working Paper No. 87. Available from: http://www.cresc.ac.uk/publications/rebalancing-the-economy-or-buyersremorse [accessed 28 February 2014].

Giovannini, Arianna (2016). 'Towards a "New English Regionalism" in the North? The Case of Yorkshire First', The Political Quarterly, 87(4), 590-600.

Haughton, Graham, Deas, Iain, Hincks, Stephen and Ward, Kevin (2016). 'Mythic Manchester: Devo Manc, the Northern Powerhouse and rebalancing the English economy', Cambridge Journal of Regions, Economy and Society, 9, 355-370.

Hayton, Richard, Giovannini, Arianna and Berry, Craig (2016). 'Introduction', in Hayton, Richard, Giovannini, Arianna and Berry, Craig (eds) The Politics of the North: governance, territory and identity in Northern England, Leeds: University of Leeds, 6-11. Available from: http://speri.dept.shef.ac.uk/wp-content/uploads/2016/01/Politics-of-theNorth-Hayton-Giovannini-Berry.pdf [accessed 14 March 2017].

Hudson, Ray (2013). 'Thatcherism and its geographical legacies: the new map of sociospatial inequality in the Divided Kingdom', The Geographical Journal, 179(4), 377-381.

Hunt, Tom, Lavery, Scott, Vittery, William, Berry, Craig (2016). 'UK regions and European structural and investment funds', SPERI British Political Economy Brief No.25. Available at: http://speri.dept.shef.ac.uk/wp-content/uploads/2016/05/Brief24-UK-regions-andEuropean-structural-and-investment-funds.pdf [accessed 14 March 2017].

Jessop, Bob (2012). 'Cultural political economy, spatial imaginaries, regional economic dynamics', CPERC Working Paper 2012-2. Available from: http://www.lancaster.ac.uk/cperc/docs/Jessop\%20CPERC\%20Working\%20Paper\%20201 2-02.pdf [accessed 14 March 2017].

Jessop, Bob (2015). The State: Past, Present, Future, Cambridge: Polity Press.

Jewell, Helen (1994). The North-South Divide: The Origins of Northern Consciousness in England, Manchester: Manchester University Press.

Lee, Simon (2015). 'Indebted and unbalanced: the political economy of the coalition', in Matt Beech and Simon Lee (eds) The Conservative-Liberal Coalition: Examining the CameronClegg Government. Basingstoke: Palgrave Macmillan, 16-35.

Los, Bart, McCann, Philip, Springford, John, Thissen, Mark (2017). 'The mismatch between local voting and the local economic consequences of Brexit', Regional Studies, forthcoming.

Martin, Ron (1993). 'Remapping British Regional Policy: The End of the North-South Divide?', Regional Studies, 27(8), 797-805.

McCann, Philip (2008). 'Globalization and economic geography: the world is curved, not flat', Cambridge Journal of Regions, Economy and Society, 1(3), 351-370.

McCann, Philip (2016). The UK Regional-National Economic Problem: Geography, Globalisation and Governance, London: Routledge.

Paasi, Anssi (2000). 'Territorial identities as social constructs', Hagar - International Social Science Review, 1(2), 91-113. 
Peck, Jamie and Theodore, Nik (2007) 'Variegated capitalism', Human Geography, 31(6), 731-772.

Pike, Andy, Coombes, Mike, O’Brien, Peter and Tomaney, John (2016). 'Austerity States, Institutional Dismantling and the Governance of Sub-National Economic Development: The Demise of the Regional Development Agencies in England', Spatial Economics Research Centre Discussion Paper 206. Available from: http://www.spatialeconomics.ac.uk/textonly/SERC/publications/download/sercdp0206.pdf [accessed 14 March 2017].

Pike, Andy and Tomaney, John (2009). 'The state and uneven development: the governance of economic development in England in the post-devolution UK', Cambridge Journal of Regions, Economy and Society, 2(1), 13-34.

Prosser, Brenton, Renwick, Alan, Giovannini, Arianna, Sandford, Mark, Flinders, Matthew, Jennings, Will, Smith, Graham, Spada, Paolo, Stoker, Gerry, Ghose, Katie (2017). 'Citizen Participation and Changing Governance: Cases of Devolution in England', Policy \& Politics, available on early view from:

http://www.ingentaconnect.com/content/tpp/pap/pre-prints/contentpppolicypold $1600087 \mathrm{r} 1$

Rowthorn, Robert and Coutts, Kenneth (2013). Deindustrialisation and the balance of payments in advanced economies, Foresight/Government Office for Science Future of Manufacturing Project Evidence Paper 31. Available from: https://www.gov.uk/government/uploads/system/uploads/attachment_data/file/283905/ep3 1-de-industrialisation-and-balance-of-payments.pdf [accessed 11 August 2016].

Tomaney, John (2016). 'Limits of Devolution: Localism, Economics and Post-democracy', The Political Quarterly, 87(4), 546-552. 